\title{
Acute Cervico-facial Oedema and Loss of Consciousness following Ingestion of Barracuda Fish
}

\author{
Maj R J T Wilson \\ MB, RAMC \\ Specialist
}

Department of Anaesthesia, Cambridge Military Hospital, Aldershot, Hampshire GU11 2AN

\author{
Maj J G McAdam \\ FRCS, RAMC
}

Specialist

Department of Surgery, British Military Hospital, Hannover, West Germany, BFPO 33

\begin{abstract}
SUMMARY: A young male presented with acute cervico-facial swelling and loss of consciousness, following ingestion of barracuda flesh. He recovered after administration of anti-histamines and steroids. Toxicity associated with barracuda is discussed.
\end{abstract}

\section{Case Report}

A 20 year old Royal Air Force bar steward was admitted to the British Forces Hospital in Belize, Central America, having been found unconscious in his room 4 hours after he had last been seen. No other history was available at that time. He had gross swelling of the neck and face, including the peri-orbital region. He was unconscious and unresponsive to painful stimuli. There were no other abnormalities of the nervous system. He was apyrexial and cardio-respiratory function was normal apart from a tachycardia of $105 /$ $\min$. He was able to maintain his own airway and had an oxygen haemoglobin saturation of $99 \%$ breathing room air.

Blood count, serum electrolytes and glucose were all normal and no obvious cause could be found for his clinical condition.

In an effort to treat the oedema, he was given chlorpheniramine $10 \mathrm{mgs}$ and hydrocortisone succinate $100 \mathrm{mgs}$ intravenously. Within 15 minutes of this treatment he had regained full consciousness and was completely orientated. During the day he had been on a boat trip to one of the offshore Carribean islands. On the trip out the local boatman had caught a barracuda, a carnivorous fish common to tropical reef waters in the Atlantic and Pacific oceans. At lunchtime the fish had been barbecued but the only people willing to eat it were the patient and the boatman; moreover, the patient claimed to have had only 1 mouthful of the fish. On returning to the camp that afternoon he had felt peculiarly tired, though not unwell, and had gone to his room to lie down. He was found 4 hours later and brought to the hospital. He had no previous history of allergy to fish and had not eaten barracuda before.

He remained in hospital for a further week; treatment consisted of hydrocortisone 100mgs 4 times daily for 2 days and chlorpheniramine $4 \mathrm{mgs} 3$ times daily for 7 days. His neck swelling subsided from $44 \mathrm{cms}$ diameter on admission to $37 \mathrm{cms}$ at 7 days. He was discharged with no further sequelae.

\section{Discussion}

The barracuda (Sphyraena barracuda) is a carnivorous fish and a known carrier of several toxins.0 Implicated are tetraodotoxin and ciguatoxin, both $\vec{P}$ naturally derived(1); barracuda are also known to haves significant accumulations of man-made toxins, namely the organochlorine pesticides such as DDT(2).

Ciguatoxin causes symptoms such as lip tingling colicky abdominal pains and painful joints; it has knowf anti-cholinesterase activity as well as other unidentified. mechanisms of action(3). Up to $70 \%$ of barracuda in the Carribean may be ciguatoxic during August(4), the month in question; however, our patient did not show the characteristic symptomatology. Neither did he exhibit the muscle weakness, respiratory depression and convulsions associated with tetraodotoxin poisoning. Acute DDT poisoning is only encountered with ingestion of very large amounts and could not be a cause here.

This case was characterised by the presence of cervico-facial oedema, rapid onset of symptoms and the recovery of consciousness following the administration of anti-histamines. Some parallels can be drawn here with scombrotoxic poisoning; the symptoms are those of histamine toxicity, onset may be within 2 hours and antihistamines produce rapid reversal of symptoms $(3,5)$. Facial swelling has been implicated in 1 reported case(5). The condition is usually associated with tuna, mackerel and other fish of the Scombroid family. Perhaps our case represents similar mechanisms of toxicity, hitherto undescribed following barracuda ingestion.

\section{REFERENCES}

1. Manson-Bahr P, Apted F. Manson's Tropical Diseases. Balliere-Tindall 1982; 544-546. 
2. Deichmann W, Cubit D, MacDonald W, Beasley A. Organochlorine Pesticides in the Tissues of the Great Barracuda (Sphyraena barracuda). Arch Toxicol 1972; 29: 287-309.

3. Goulding R. Poisoning. Blackwell Scientific Publications $1983 ; 213-214$.

4. Tosteson T, Ballantine D, Durst H. Seasonal frequency of ciguatoxic barracuda in southwest Puerto Rico. Toxicon 1988; 26: 795-801.

5. Gilbert R, Hobbs G, Murray C, Cruikshank J, Young $\mathrm{S}$. Scombrotoxic fish poisoning: features of the first 50 incidents to be reported in Britain (1976-9). Br Med J 1980; 281: $71-72$.

\section{THE ROYAL BRITISH LEGION POPPY APPEAL 1990}

\section{POPPY CARE}

1990 is the 50th anniversary of Dunkirk and the Battle of Britain, and these milestones serve to remind us all of the debt we owe to our Armed Forces.

The Royal British Legion has been helping the exService community, not for 50 years, but since 1921 . It seeks to relieve need among those who have served in any of the British Forces, at any time, and their widows and dependants.

1990 will be the 70th Poppy Appeal and the British public has never let it down. A record of almost $f 12$ million in 1989 says that there is absolutely no sign that the public will fail to support it fully. It is a British Institution - universally recognised and respected.

Research tells us that more of the population gives to the Poppy Appeal than any other national charity there is tremendous public support. The public knows that the Poppy Appeal is a cost-effective charity - only seven pence in the pound is spent on administration and fund raising. Put the other way, 93 percent goes to benevolent services like residential and convalescent homes, sheltered employment, advice on pensions and a whole range of schemes designed to meet the particular needs of the ex-Service community.

That need is increasing as the ex-Service population gets older. The Appeal must raise more money if services are to be sustained and improved. A muchneeded seventh residential home alone will cost $£ 6$ million. Currently the Legion helps around 100,000 people each year and it is estimated that no less than about 18 million - one in three of the population - are eligible in case of need.

1990 is a year when FREEDOM is the thought uppermost in many minds throughout the world. In this country we have it in a measure which is still the envy of many. However, it was preserved at great sacrifice, and The Royal British Legion seeks through the Poppy Appeal to help those whose personal sacrifice has helped - and is still helping - to sustain and protect our free way of life.

So, in 1990 , as we read of dramatic events in other parts of the world - GIVE THANKS FOR YOUR FREEDOM - GIVE MORE FOR YOUR POPPY and, if you can - GIVE A POUND! 